\title{
Guillain-Barré syndrome associated with SARS-CoV-2 infection: a scoping review
}

\author{
Kleyton Santos de Medeiros ${ }^{1} \mathbb{1}$, Luíza Thomé de Araújo Macêdo ${ }^{2}$, \\ Wederson Farias de Souza ${ }^{~}\left(\mathbb{D}\right.$, Ayane Cristine Sarmento ${ }^{1}$ (D), \\ Ana Paula Ferreira Costa ${ }^{1}$ (D), Ana Katherine Gonçalves ${ }^{1,3 *}$ (1)
}

\section{SUMMARY}

BACKGROUND: Severe acute respiratory syndrome coronavirus 2 (SARS-CoV-2) infections can affect the nervous system, triggering problems such as the Guillain-Barre Syndrome (GBS), an association that can bring complications to the patient.

OBJECTIVE: This scoping review aimed to clarify the clinical features and analyze patients with GBS associated with SARS-CoV-2 infection, looking at morbidity, mortality, and neurological outcomes.

SEARCH STRATEGY: The search was conducted through Medline, Web of Science, Embase, CINAHAL, Latin-American and Caribbean Literature in Health Sciences (LILACS), clinicaltrials.gov, SCOPUS, and the Cochrane Central Register of Controlled Trials.

SELECTION CRITERIA: Observational studies, published after 2019, describe patients with GBS associated with SARS-CoV-2 infection. There were no language restrictions while selecting the studies.

DATA COLLECTION AND ANALYSIS: Three authors, Kleyton Santos de Medeiros, Luíza Thomé de Araújo Macêdo, and Wederson Farias de Souza, independently screened the search results using titles and abstracts. Duplicate studies were excluded. The same authors then went through the entire text to determine whether the studies met the inclusion criteria. Discrepancies were resolved by other reviewers, Ana Paula Ferreira Costa, Ayane Cristine Sarmento, and Ana Katherine Gonçalves. Finally, the selection of the studies was summarized in a PRISMA flow diagram.

MAIN RESULTS: Main manifestations were fever, coughing, dyspnea, sore throat, ageusia, anosmia, and respiratory failure, in addition to paresthesia of the upper and lower limbs, tetraparesis, facial diplegia, areflexia, asthenia, mastoid pain, acute ataxia, fatigue, numbness, swallowing disorder, and moderate low back pain.

CONCLUSION: Coronavirus disease 2019 (COVID-19) can trigger the GBS, despite the few studies on this topic. Patients had clinical manifestations of COVID-19 infection and neurological manifestations characterizing GBS.

KEYWORDS: Coronavirus infections. COVID-19. Guillain-Barre syndrome.

\section{INTRODUCTION}

In December 2019, an outbreak of SARS-CoV-2, the virus that causes COVID-19 was detected in Wuhan City, Hubei Province of China. COVID-19 primarily affects the respiratory tract and the lungs and the appearance of symptoms depends on the age and the patient's underlying medical illness as well as on the condition of the immune system ${ }^{1,2}$.

\footnotetext{
'Universidade Federal do Rio Grande do Norte, Pós-Graduação em Ciências da Saúde - Natal (RN), Brazil.

${ }^{2}$ Centro Universitário do Rio Grande do Norte - Natal (RN), Brazil.

${ }^{3}$ Universidade Federal do Rio Grande do Norte, Departamento de Toco-Ginecologia - Natal (RN), Brazil.

*Corresponding author: anakatherine_ufrnet@yahoo.com.br

Conflicts of interest: the authors declare there are no conflicts of interest. Funding: none.

Received on August 21, 2020. Accepted on August 30, 2020.
} 
Infected individuals usually have simple respiratory symptoms, fever, dry cough, and tiredness, which can progress to pneumonia and dyspnea ${ }^{3}$. The reported neurological manifestations and complications of COVID-19 include anosmia, headaches, dizziness, delirium, stroke, epilepsy, encephalitis, encephalopathy, myalgias, and Guillain-Barré syndrome $(\mathrm{GBS})^{1,2,4}$.

GBS is an acute immune-mediated disease of the peripheral nerves and nerve roots (polyradiculoneuropathy) usually preceded by various infections ${ }^{2}$. Classical clinical manifestations include paresthesia, progressive, ascending, and symmetrical flaccid limbs paralysis, muscle weakness, and areflexia. It may also present an infection of the gastrointestinal or respiratory tract before neurological symptoms ${ }^{1}$.

The aims of this scoping review was to clarify the clinical features of patients with GBS associated with SARS-CoV-2 infection, their morbidity and mortality, as well as this important neurological manifestation caused by COVID-19.

\section{METHODS}

The Scoping Review was carried out following the Preferred Reporting Items for Systematic reviews and Meta-Analyses extension for Scoping Reviews (PRISMA-ScR) checklist 5 .

\section{Protocol and registration}

The review was not registered in the International Prospective Register of Systematic Reviews (PROSPERO), and corresponding authors were not contacted due to time constraints. Ethical approval was not required for this review.

\section{Eligibility criteria}

This scoping review included the following studies: observational studies (case report, case series, case-control, and cohort) describing patients with GBS associated with SARS-CoV-2 infection; and studies published after 2019, as the first case of COVID-19 was registered in Wuhan, China, in December $2019^{6}$. There were no language restrictions while selecting studies.

\section{Information Sources}

Medline, Web of Science, Embase, Cumulative Index to Nursing and Allied Health Literature (CINAHAL), Latin American and Caribbean Literature in Health Sciences (LILACS), clinicaltrials.gov, Scopus, and the Cochrane Central Register of Controlled Trials were used to search for articles published between December 2019 and April 2020. We selected the publications starting from December 2019 because the first case of COVID-19 was registered in Wuhan, China, in December $2019^{6}$.

\section{Search}

The medical subject headings (MESH) terms were (COVID19 OR severe acute respiratory syndrome coronavirus 2 OR SARS-CoV-2) AND (Guillain Barre Syndrome OR Guillain-Barré Syndrome OR Landry-Guillain-Barre Syndrome OR Acute Autoimmune Neuropathy). Eligible studies were also selected from the reference lists of the retrieved articles. The research included articles published until June $26^{\text {th }}$.

\section{Selection of sources of evidence}

Three authors, KSM, LTAM, and WFS, independently screened the search results using the titles and abstracts. Duplicate studies were excluded. The same authors then went through the full text to determine whether the studies met the inclusion criteria. Discrepancies were resolved by others reviewers, APFC, ACAS, and AKG. The selection of the studies was summarized in a PRISMA flow diagram (Figure 1).

\section{Data items and Synthesis of results}

Various characteristics of the eligible studies were extracted, including the first authors' last names, year of publication, location of the study (country), study design, primary objective, level of evidence, number of patients, gender, mean age of patients, comorbidities, clinical manifestations, muscle strength assessment, patient outcome, chest imaging, laboratory tests, tests diagnosis, and treatment. Standardized data extraction forms were specifically created in Excel for this review, and the results were entered into a database. All data entries were double-checked. Subsequently, the qualitative synthesis was summarized.

\section{Critical appraisal of individual sources of evidence}

The quality of the included studies was assessed using the New JBI Levels of Evidence developed by the Joanna Briggs Institute Levels of Evidence and Grades of Recommendation Working Party of October 20137. Then, a Checklist for Case Series ${ }^{8}$ and a Checklist for case reports were used?.

\section{RESULTS}

\section{Selection of sources of evidence}

The database search identified 196 articles. Excluding duplicates, a total of thirty-eight articles; one hundred and fifty-eight were considered eligible. However, forty-seven were excluded because titles and abstracts were considered 
irrelevant to the topic or published before 2019. Subsequently, one hundred and eleven full-text articles were identified and assessed for eligibility. However, eighty-two publications were excluded because the data was insufficient to be extracted or calculated. Thus, twenty-nine articles were analyzed. The PRISMA-ScR flowchart for selecting the available studies is shown in Figure 1.

\section{Characteristics of sources of evidence}

The articles were carried out in different places, being $\operatorname{Iran}^{1}$, Italy $^{10-15}$, China ${ }^{16}$, the United States ${ }^{17-20}$, France ${ }^{21-24}$, Spain ${ }^{25-}$ ${ }^{30}$, Canada $^{31}$, Switzerland ${ }^{32,33}$, Austria ${ }^{34}$, Holland ${ }^{35}$, Turkey ${ }^{36}$, and Germany ${ }^{37}$. Twenty-seven articles were in English and three in Spanish, published in 2020 and presented in the data extraction Table 1.

\section{Critical appraisal within sources of evidence}

Twenty-six articles were case reports (level of evidence 4.d) and three case series (level of evidence 4.c). Therefore, it was observed that the studies included in this review have low levels of evidence, according to the New Levels of Evidence from $\mathrm{JBI}^{7}$. This can be explained due to the recent appearance of the disease.

Despite this, all studies were well designed and well evaluated by the JBI Critical Appraisal Checklist for Case Series ${ }^{8}$ and
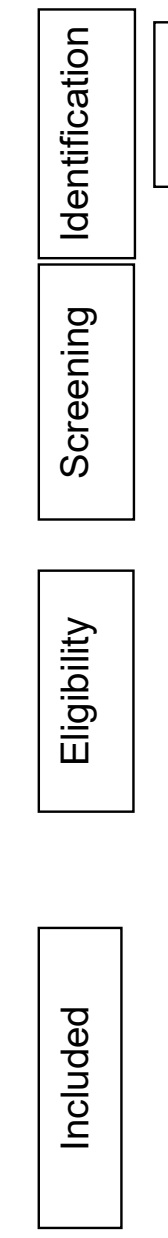

Records excluded:

Reviews: $(n=0)$

Titles and abstracts irrelevant to the topic or published before 2019: $(n=47)$
Records excluded:

Publications that are not specifically about COVID-19 and Guillain-Barre Syndrome $(n=0)$ Insufficient data to be extracted or calculated: $(n=82)$

\section{Studies included in the qualitative synthesis}

$(n=29)$

Figure 1. Flow diagram of the search for eligible studies COVID-19 and Guillain-Barre Syndrome: CENTRAL. Cochrane Central Register of Controlled Trials. 
Table 1. Description of the characteristics of included studies.

\begin{tabular}{|c|c|c|c|c|c|c|c|c|}
\hline Author & Gender & Age & Comorbidities & $\begin{array}{c}\text { Clinical } \\
\text { manifestations }\end{array}$ & Patient outcome & Chest imaging & Treatment & Diagnosis \\
\hline $\begin{array}{l}\text { Sedaghat } \\
\text { et al. }{ }^{1}\end{array}$ & Male & 65 & $\begin{array}{l}\text { Diabetes } \\
\text { Mellitus } 2\end{array}$ & $\begin{array}{c}\text { Presented } \\
\text { neurological } \\
\text { manifestations such } \\
\text { as acute progressive } \\
\text { weakness of the distal } \\
\text { lower extremities, } \\
\text { progressing from } \\
\text { the distal to the } \\
\text { proximal limbs and, } \\
\text { shortly afterward, } \\
\text { he presented } \\
\text { quadriplegia and } \\
\text { facial paresis } \\
\text { bilaterally. }\end{array}$ & $\begin{array}{l}\text { On physical } \\
\text { examination, the } \\
\text { patient had normal } \\
\text { vital symptoms and } \\
\text { was conscious. }\end{array}$ & $\begin{array}{l}\text { CT showed diffused } \\
\text { consolidations } \\
\text { and ground-glass } \\
\text { opacities in both } \\
\text { lungs, and bilateral } \\
\text { pleural effusion. }\end{array}$ & $\begin{array}{l}\text { Hydroxychloroquine, } \\
\text { LPV/RTV, and } \\
\text { Azithro- mycin. } \\
\text { And } 0.40 \mathrm{~g} / \mathrm{kg} / \\
\text { day IVIg; and } \\
\text { metformin } 2 \\
\text { diabetes mellitus. }\end{array}$ & $\begin{array}{l}\text { RT- PCR; } \\
\text { chest CT } \\
\text { and EMG. }\end{array}$ \\
\hline \multirow{5}{*}{$\begin{array}{l}\text { Toscano } \\
\text { et al. }{ }^{10}\end{array}$} & $\begin{array}{l}\text { P1 - } \\
\text { Female }\end{array}$ & 77 & NA & $\begin{array}{l}\text { Paresthesia in the } \\
\text { lower limbs and } \\
\text { hands. Flaccid } \\
\text { areflexic tetraplegia } \\
\text { evolving to facial } \\
\text { weakness, upper- } \\
\text { limb paresthesia (36 } \\
\text { h), and respiratory } \\
\text { failure (day 6) }\end{array}$ & $\begin{array}{l}\text { Lymphocytopenia, } \\
\text { Raised CRP, LDH, } \\
\text { and ketonuria. }\end{array}$ & $\begin{array}{l}\text { CT scan of the } \\
\text { thorax revealed } \\
\text { interstitial bilateral } \\
\text { pneumonia. }\end{array}$ & IVlg treatment. & $\begin{array}{l}\text { RT-PCR and } \\
\text { EMG. }\end{array}$ \\
\hline & $\begin{array}{l}\text { P2 - } \\
\text { Male }\end{array}$ & 23 & NA & $\begin{array}{l}\text { Upper and lower } \\
\text { facial weakness, } \\
\text { which became } \\
\text { bilateral and } \\
\text { complete within } 2 \\
\text { days, accompanied } \\
\text { by mastoid pain, loss } \\
\text { of taste, and lower } \\
\text { limb paresthesia. }\end{array}$ & $\begin{array}{l}\text { Lymphocytopenia, } \\
\text { raised ferritine, CRP, } \\
\text { LDH, and AST. }\end{array}$ & $\begin{array}{l}\text { Normal thorax } \\
\text { imaging. }\end{array}$ & $\begin{array}{l}\text { Amoxicillin for five } \\
\text { days and IVIg. }\end{array}$ & $\begin{array}{l}\text { RT-PCR, } \\
\text { EMG, and } \\
\text { brain MRI. }\end{array}$ \\
\hline & $\begin{array}{l}\text { P3- } \\
\text { Male }\end{array}$ & 55 & NA & $\begin{array}{l}\text { Flaccid tetraparesis } \\
\text { and facial weakness } \\
\text { evolving to areflexia } \\
\text { (day 2) and } \\
\text { respiratory failure } \\
\text { (day 5). }\end{array}$ & $\begin{array}{l}\text { Lymphocytopenia, } \\
\text { raised CRP, LDH, } \\
\text { AST, GGT, and } \\
\text { ketonuria. }\end{array}$ & $\begin{array}{l}\text { A CT scan of the } \\
\text { thorax revealed } \\
\text { multiple bilateral, } \\
\text { ground-glass } \\
\text { opacities compatible } \\
\text { with interstitial } \\
\text { pneumonia. }\end{array}$ & $\begin{array}{l}\text { Azithromycin and } \\
\text { received } 2 \text { cycles } \\
\text { of IVlg. }\end{array}$ & $\begin{array}{l}\text { RT-PCR and } \\
\text { EMG. }\end{array}$ \\
\hline & $\begin{array}{l}\text { P4- } \\
\text { Male }\end{array}$ & 76 & NA & $\begin{array}{l}\text { Lumbar pain and } \\
\text { lower limb weakness } \\
\text { and, on the } 4^{\text {th }} \text { day } \\
\text { after admission, } \\
\text { muscle weakness } \\
\text { rapidly evolved to } \\
\text { a flaccid areflexic } \\
\text { tetraparesis. }\end{array}$ & $\begin{array}{l}\text { Lymphocytopenia, } \\
\text { raised CRP, } \\
\text { ketonuria. } \\
\text { IVIg treatment } \\
\text { resulted in motor } \\
\text { improvement, more } \\
\text { evident in upper } \\
\text { limbs, but still } \\
\text { unable to stand. }\end{array}$ & $\begin{array}{l}\text { Normal thorax } \\
\text { imaging. }\end{array}$ & IVlg treatment. & RT-PCR \\
\hline & $\begin{array}{l}\text { P5 - } \\
\text { Male }\end{array}$ & 61 & NA & $\begin{array}{l}\text { Complained of } \\
\text { asthenia, loss of } \\
\text { taste and smell, for } \\
\text { one week. }\end{array}$ & $\begin{array}{l}\text { Lymphocytopenia, } \\
\text { raised CRP, LDH, } \\
\text { and AST. Developed } \\
\text { respiratory failure } \\
\text { with neuromuscular } \\
\text { features } \\
\text { (hypercapnia, } \\
\text { paradox respiration, } \\
\text { acidosis) and } \\
\text { was referred to } \\
\text { the ICU, were he } \\
\text { received mechanical } \\
\text { ventilation through } \\
\text { tracheostomy. The } \\
\text { patient developed } \\
\text { acinetobacter } \\
\text { pneumonia. }\end{array}$ & $\begin{array}{l}\text { Thorax X-ray and CT } \\
\text { showed interstitial } \\
\text { pneumonia, without } \\
\text { parenchymal } \\
\text { opacities nor } \\
\text { alveolar damage. }\end{array}$ & $\begin{array}{l}\text { Received IVIg and } \\
\text { plasma exchange; } \\
\text { had bacterial } \\
\text { pneumonia during } \\
\text { IVIg treatment, } \\
\text { which delayed } \\
\text { plasma exchange. }\end{array}$ & $\begin{array}{l}\text { RT-PCR and } \\
\text { EMG. }\end{array}$ \\
\hline
\end{tabular}


Table 1. Continuation.

\begin{tabular}{|c|c|c|c|c|c|c|c|c|}
\hline Author & Gender & Age & Comorbidities & $\begin{array}{c}\text { Clinical } \\
\text { manifestations }\end{array}$ & Patient outcome & Chest imaging & Treatment & Diagnosis \\
\hline $\begin{array}{l}\text { Padroni } \\
\text { et al. }{ }^{11}\end{array}$ & Female & 70 & NA & $\begin{array}{l}\text { Complaining of } \\
\text { asthenia, hands and } \\
\text { feet paresthesia, } \\
\text { and gait difficulties } \\
\text { progressing within } \\
1 \text { day. On March } 4^{\text {th }} \\
\text { she had developed } \\
\text { fever (BT P }=38.5^{\circ} \mathrm{C} \text { ) } \\
\text { and dry cough. }\end{array}$ & $\begin{array}{l}\text { Arterial blood gas } \\
\text { analysis showed } \\
\mathrm{pO}_{2}=76 \mathrm{mmHg} \text { with } \\
\text { normal p/f ratio } \\
(=363) \text {. The patient } \\
\text { was intubated } \\
\text { and mechanical } \\
\text { ventilation was } \\
\text { applied, because of } \\
\text { respiratory failure due } \\
\text { to the worsening of } \\
\text { muscle weakness. }\end{array}$ & $\begin{array}{l}\text { A chest high- } \\
\text { resolution } \\
\text { computed } \\
\text { tomography } \\
\text { revealed some small } \\
\text { "ground glass" } \\
\text { areas in both lungs. }\end{array}$ & $\begin{array}{l}\text { IVlg } 400 \mathrm{mg} / \text { die for } \\
5 \text { days was started. }\end{array}$ & $\begin{array}{l}\text { RT-PCR } \\
\text { and the } \\
\text { neurological } \\
\text { examination } \\
\text { disclosed } \\
\text { moderate. }\end{array}$ \\
\hline $\begin{array}{l}\text { Alberti } \\
\text { et al. }{ }^{12}\end{array}$ & Male & 71 & $\begin{array}{l}\text { Hypertension, } \\
\text { abdominal } \\
\text { aortic } \\
\text { aneurysm, } \\
\text { and lung } \\
\text { cancer } \\
\text { treated with } \\
\text { surgery only } \\
\text { in } 2017 \text { with } \\
\text { negative } \\
\text { oncological } \\
\text { follow-up; } \\
\text { no previous } \\
\text { neurologic } \\
\text { history was } \\
\text { reported. }\end{array}$ & $\begin{array}{l}\text { Paresthesia at limb } \\
\text { extremities, followed by } \\
\text { distal weakness rapidly } \\
\text { evolving to a severe, } \\
\text { flaccid tetraparesis } \\
\text { over the previous } \\
3 \text { days. Neurologic } \\
\text { examination showed } \\
\text { symmetric limb } \\
\text { weakness, symmetric } \\
\text { and extensive stocking- } \\
\text { and-glove hypesthesia } \\
\text { at the } 4 \text { limbs (more } \\
\text { pronounced at lower } \\
\text { limbs), absent deep } \\
\text { tendon reflexes, } \\
\text { and normal plantar } \\
\text { response. Moderate } \\
\text { low back pain were } \\
\text { present. }\end{array}$ & $\begin{array}{c}\text { He showed } \\
\text { hemodynamic } \\
\text { disturbances with } \\
\text { severe drug-resistant } \\
\text { hypertension. } \\
\text { Arterial blood gases } \\
\text { indicated severe } \\
\text { hypoxia (paO } 65 \\
\text { mm Hg without } \\
\text { supplemental } \\
\text { oxygen). } \\
\text { Unresponsive to } \\
\text { continuous positive } \\
\text { airway pressure } \\
\text { ventilation and prone } \\
\text { positioning. The } \\
\text { patient died a few } \\
\text { hours later because } \\
\text { of progressive } \\
\text { respiratory failure. }\end{array}$ & $\begin{array}{l}\text { Brain CT scan was } \\
\text { normal, whereas } \\
\text { chest CT scan } \\
\text { showed multiple } \\
\text { bilateral ground } \\
\text { glass opacities and } \\
\text { consolidations, } \\
\text { typical of COVID-19 } \\
\text { pneumonia. }\end{array}$ & $\begin{array}{l}\text { High-dose IV } \\
\text { immunoglobulins } \\
\text { (0.4 g/kg/d for } \\
5 \text { days) were } \\
\text { started few hours } \\
\text { after admission, } \\
\text { together with } \\
\text { high-flow } 60 \%- \\
80 \% \text { oxygen via } \\
\text { nonrebreather } \\
\text { mask, antiviral } \\
\text { therapy (LPV } \\
\text { + RTV), and } \\
\text { hydroxychloroquine }\end{array}$ & $\begin{array}{l}\text { RT- PCR; } \\
\text { chest CT } \\
\text { and EMG. }\end{array}$ \\
\hline \multirow[b]{2}{*}{$\begin{array}{l}\text { Assini } \\
\text { et al. }{ }^{13}\end{array}$} & $\begin{array}{l}\text { P1 - } \\
\text { Male }\end{array}$ & 55 & NA & $\begin{array}{l}\text { Severe respiratory } \\
\text { syndrome preceded } \\
\text { by anosmia and } \\
\text { ageusia, fever, and } \\
\text { cough; acute onset } \\
\text { of bilateral eyelid } \\
\text { ptosis, dysphagia, } \\
\text { and dysphonia. }\end{array}$ & $\begin{array}{l}\text { Neurological } \\
\text { examination showed } \\
\text { bilateral masseter } \\
\text { weakness, tongue } \\
\text { protrusion deficit due } \\
\text { to bilateral paralysis of } \\
\text { the hypoglossal nerve, } \\
\text { and hyporeflexia of } \\
\text { upper and lower } \\
\text { limbs, without muscle } \\
\text { weakness. The patient } \\
\text { was moved to ICU for } \\
\text { invasive ventilation. } \\
\text { Lymphocytopenia. }\end{array}$ & NA & $\begin{array}{c}\text { Hydroxychloroquine, } \\
\text { Arbidol, RTV and } \\
\text { LPV; IVIg. }\end{array}$ & $\begin{array}{l}\text { RT- PCR; } \\
\text { EMG. }\end{array}$ \\
\hline & $\begin{array}{l}\text { P2 - } \\
\text { Male }\end{array}$ & 60 & NA & $\begin{array}{l}\text { Fever and cough; } \\
\text { weakness in lower } \\
\text { limbs with distal } \\
\text { distribution and foot } \\
\text { drop on the right } \\
\text { side. }\end{array}$ & $\begin{array}{l}\text { Simultaneously, } \\
\text { massive disorders } \\
\text { of the vegetative } \\
\text { nervous system, } \\
\text { consisting of } \\
\text { gastroplegia, paralytic } \\
\text { ileus, and loss of } \\
\text { blood pressure control } \\
\text { occurred. Neurological } \\
\text { examination showed } \\
\text { distal weakness } \\
\text { at four limbs, } \\
\text { with foot drop. } \\
\text { Tracheostomy and } \\
\text { assisted ventilation. } \\
\text { Blood tests showed } \\
\text { lymphocytopenia, } \\
\text { increased LDH } \\
\text { and GGT, and } \\
\text { leukocytosis. }\end{array}$ & NA & $\begin{array}{l}\text { Hydroxychloroquine, } \\
\text { antiretroviral } \\
\text { therapy, and } \\
\text { tocilizumab. IVlg } \\
\text { therapy. }\end{array}$ & $\begin{array}{l}\text { RT-PCR and } \\
\text { thoracic CT } \\
\text { scan. }\end{array}$ \\
\hline
\end{tabular}


Table 1. Continuation.

\begin{tabular}{|c|c|c|c|c|c|c|c|c|}
\hline Author & Gender & Age & Comorbidities & $\begin{array}{c}\text { Clinical } \\
\text { manifestations }\end{array}$ & Patient outcome & Chest imaging & Treatment & Diagnosis \\
\hline $\begin{array}{l}\text { Ottaviani } \\
\text { et al. }{ }^{14}\end{array}$ & Female & 66 & NA & $\begin{array}{l}\text { History of increasing } \\
\text { difficulty walking and } \\
\text { acute fatigue; she had } \\
\text { mild fever and cough } \\
10 \text { days earlier. She also } \\
\text { manifested a transient } \\
\text { pruriginous dorsal rash, } \\
\text { in addition to mild } \\
\text { hypertension treated } \\
\text { with beta-blockers. } \\
\text { On evaluation, she } \\
\text { was paraparetic with } \\
\text { a rapidly progressive } \\
\text { symmetric weakness in } \\
\text { the lower limbs, leading } \\
\text { to falls and paraplegia. } \\
\text { Progressively developed } \\
\text { proximal weakness in } \\
\text { all limbs, dysesthesia, } \\
\text { and unilateral facial } \\
\text { palsy. }\end{array}$ & $\begin{array}{l}\text { Maintaining } \\
\text { reasonable } \\
\text { respiratory function } \\
\text { with supplemental } \\
\text { oxygen. Moreover, } \\
\text { gas exchanges } \\
\text { worsened } \\
\text { with a sudden } \\
\text { desaturation, } \\
\text { requiring intubation } \\
\text { and ICU admission, } \\
\text { where she was } \\
\text { treated for multi- } \\
\text { organ failure along } \\
\text { with a leg deep } \\
\text { vein thrombosis and } \\
\text { a superimposed } \\
\text { bacterial infection } \\
\text { (ab ingestis } \\
\text { pneumonia). }\end{array}$ & $\begin{array}{l}\text { Lung CT scan } \\
\text { showed bilateral } \\
\text { ground glass } \\
\text { opacities. }\end{array}$ & $\begin{array}{l}\text { IVIg; antiretroviral } \\
\text { drugs (LPV } \\
\text { and RTV) and } \\
\text { hydroxychloroquine. }\end{array}$ & $\begin{array}{l}\text { RT-PCR } \\
\text { and the } \\
\text { neurological } \\
\text { examination } \\
\text { disclosed } \\
\text { moderate } \\
\text { (Medical } \\
\text { Research } \\
\text { Council } \\
\text { grade 4/5). }\end{array}$ \\
\hline Riva et al. ${ }^{15}$ & Male & 60 & NA & $\begin{array}{l}\text { Three-day history } \\
\text { of progressive limb } \\
\text { weakness and } \\
\text { distal paresthesia } \\
\text { at four-limbs. His } \\
\text { past medical history } \\
\text { was unremarkable. } \\
\text { Twenty days before, } \\
\text { he had developed } \\
\text { fever ( } 37.7-38.5 \\
\left.{ }^{\circ} \mathrm{C}\right) \text {, headache, and } \\
\text { myalgia followed by } \\
\text { anosmia and ageusia. }\end{array}$ & $\begin{array}{l}\text { Cell blood count, } \\
\text { CRP, creatine } \\
\text { phosphokinase, } \\
\text { arterial blood } \\
\text { gases, renal and } \\
\text { hepatic function } \\
\text { tests were normal. } \\
\text { Anti-ganglioside } \\
\text { antibodies tested } \\
\text { negative. }\end{array}$ & $\begin{array}{l}\text { Chest CT scan } \\
\text { showed bilateral } \\
\text { ground-glass } \\
\text { opacities, consistent } \\
\text { with COVID-19 } \\
\text { pneumonia. }\end{array}$ & IVlg; & $\begin{array}{l}\text { Antibodies } \\
\text { for SARS- } \\
\text { CoV-2 } \\
\text { IgM/lgG } \\
\text { and the } \\
\text { neurological } \\
\text { examination } \\
\text { disclosed } \\
\text { moderate. }\end{array}$ \\
\hline Zhao et al. ${ }^{16}$ & Female & 61 & NA & $\begin{array}{c}\text { Presented with } \\
\text { acute weakness in } \\
\text { both legs and severe } \\
\text { fatigue. Neurological } \\
\text { examination } \\
\text { disclosed symmetric } \\
\text { weakness. }\end{array}$ & $\begin{array}{l}\text { Her clinical condition } \\
\text { improved gradually } \\
\text { and her lymphocyte } \\
\text { and thrombocyte } \\
\text { counts normalized } \\
\text { on day } 20 \text {. At } \\
\text { discharge on day } \\
30, \text { she had normal } \\
\text { muscle strength } \\
\text { in both arms and } \\
\text { legs and return of } \\
\text { tendon reflexes in } \\
\text { both legs and feet. }\end{array}$ & $\begin{array}{l}\text { Chest CT showed } \\
\text { ground-glass } \\
\text { opacities in both } \\
\text { lungs. }\end{array}$ & $\begin{array}{l}\text { IVIg; infection } \\
\text { isolation room and } \\
\text { received supportive } \\
\text { care and antiviral } \\
\text { drugs of arbidol, } \\
\text { LPV, and RTV. }\end{array}$ & RT-PCR \\
\hline $\begin{array}{l}\text { Virani } \\
\text { et al. }{ }^{17}\end{array}$ & Male & 54 & NA & $\begin{array}{l}\text { Complaints of } \\
\text { numbness and } \\
\text { weakness of his } \\
\text { lower extremities } \\
\text { of 2-day duration. } \\
\text { The weakness } \\
\text { progressed. The } \\
\text { patient complained } \\
\text { of difficulty } \\
\text { breathing and } \\
\text { weakness was noted } \\
\text { to ascend up to his } \\
\text { nipples. }\end{array}$ & $\begin{array}{l}\text { He was electively } \\
\text { placed on mechanical } \\
\text { ventilator support } \\
\text { for concerns of } \\
\text { impending respiratory } \\
\text { failure. His clinical } \\
\text { course showed } \\
\text { improvement in his } \\
\text { respiratory status } \\
\text { with liberation } \\
\text { from mechanical } \\
\text { ventilation on day } \\
4 \text { of IVlg therapy. } \\
\text { Neurologically, his } \\
\text { upper extremity } \\
\text { weakness resolved } \\
\text { after completion of } \\
\text { the course of IVlg. } \\
\text { Lower extremity } \\
\text { weakness persisted. }\end{array}$ & $\begin{array}{l}\text { MRI of thoracic and } \\
\text { lumbar spine that } \\
\text { did not reveal any } \\
\text { abnormal spinal } \\
\text { pathology. This } \\
\text { imaging, however, } \\
\text { did reveal incidental } \\
\text { findings of bilateral } \\
\text { basilar opacities in } \\
\text { the lungs. }\end{array}$ & $\begin{array}{l}\text { Oral amoxicillin } \\
\text { and steroids. } \\
400 \mathrm{mg} / \mathrm{kg} \text { of } \\
\text { IVlg therapy } \\
\text { for a planned } \\
\text { 5-day course. } \\
\text { Hydroxychloroquine } \\
400 \mathrm{mg} \text { for the } \\
\text { first two doses } \\
\text { with subsequent } \\
200 \text { mg dose } \\
\text { twice a day for an } \\
\text { additional eight } \\
\text { doses. }\end{array}$ & $\begin{array}{l}\text { RT-PCR and } \\
\text { MRI. }\end{array}$ \\
\hline
\end{tabular}


Table 1. Continuation.

\begin{tabular}{|c|c|c|c|c|c|c|c|c|}
\hline Author & Gender & Age & Comorbidities & $\begin{array}{c}\text { Clinical } \\
\text { manifestations }\end{array}$ & Patient outcome & Chest imaging & Treatment & Diagnosis \\
\hline Rana et al. ${ }^{18}$ & Male & 54 & $\begin{array}{l}\text { Hypertension, } \\
\text { hyperlipidemia, } \\
\text { restless leg } \\
\text { syndrome, } \\
\text { and chronic } \\
\text { back pain. }\end{array}$ & $\begin{array}{l}\text { Ascending limb } \\
\text { weakness and } \\
\text { numbness that } \\
\text { followed symptoms of } \\
\text { a respiratory infection. } \\
\text { Two weeks before } \\
\text { presentation, he initially } \\
\text { developed rhinorrhea, } \\
\text { odynophagia, fevers, } \\
\text { chills, and night sweats; } \\
\text { he developed watery } \\
\text { diarrhea; Over the next } \\
\text { few days, he noted } \\
\text { worsening paresthesias } \\
\text { of his distal extremities } \\
\text { bilaterally. His symptoms } \\
\text { progressed to weakness } \\
\text { of all limbs and } \\
\text { difficulty voiding urine, } \\
\text { developed progressive } \\
\text { shortness of breath } \\
\text { requiring intubation. } \\
\text { Quadriparesis and } \\
\text { areflexia with mute } \\
\text { plantar responses. }\end{array}$ & $\begin{array}{l}\text { He was extubated } \\
\text { on hospital day } 4 . \\
\text { On hospital day } 7 \text {, } \\
\text { he was discharged } \\
\text { to an inpatient } \\
\text { rehabilitation } \\
\text { facility. While } \\
\text { in the inpatient } \\
\text { rehabilitation, he } \\
\text { was noted to have } \\
\text { resting tachycardia } \\
\text { and persistent } \\
\text { difficulty urinating, } \\
\text { which eventually } \\
\text { required an } \\
\text { indwelling catheter. } \\
\text { He reported burning } \\
\text { dysesthesias in his } \\
\text { distal extremities } \\
\text { and trunk, and } \\
\text { complained of } \\
\text { diplopia, which was } \\
\text { worse on rightward. }\end{array}$ & $\begin{array}{l}\text { Chest X-ray was } \\
\text { negative other } \\
\text { than an incidental } \\
\text { finding of bibasilar } \\
\text { lung infiltrates } \\
\text { versus atelectasis. } \\
\text { MRI of the thoracic } \\
\text { and lumbar spine } \\
\text { was reported to } \\
\text { show no evidence } \\
\text { of myelopathy or } \\
\text { radiculopathy. }\end{array}$ & $\begin{array}{c}\text { Amoxicillin; } \\
\text { metronidazole. } \\
\text { Hydroxychloroquine } \\
\text { and azithromycin; } \\
\text { IVlg. }\end{array}$ & $\begin{array}{l}\text { RT-PCR; the } \\
\text { neurological } \\
\text { examination } \\
\text { disclosed } \\
\text { moderate } \\
\text { (Medical } \\
\text { Research } \\
\text { Council } \\
\text { grade 4/5) } \\
\text { and EMG. }\end{array}$ \\
\hline Su et al. ${ }^{19}$ & Male & 72 & $\begin{array}{l}\text { Coronary } \\
\text { artery } \\
\text { disease, } \\
\text { hypertension, } \\
\text { and alcohol } \\
\text { abuse }\end{array}$ & $\begin{array}{l}\text { Symmetric aresthesias } \\
\text { and ascending } \\
\text { appendicular } \\
\text { weakness. Seven days } \\
\text { earlier he had mild } \\
\text { diarrhea, anorexia, } \\
\text { and chills, without } \\
\text { fever or respiratory } \\
\text { symptoms. This } \\
\text { condition resolved in } 5 \\
\text { days. Weakness began } \\
6 \text { days after diarrhea, } \\
\text { and the patient } \\
\text { presented } 1 \text { day after } \\
\text { neurological symptom } \\
\text { onset. On admission, } \\
\text { he was afebrile with } \\
\text { normal vital signs. } \\
\text { Mental status and CN } \\
\text { were normal. }\end{array}$ & $\begin{array}{l}\text { On day } 3 \text {, the patient } \\
\text { developed respiratory } \\
\text { distress with a } \\
\text { negative inspiratory } \\
\text { force of }-20 \mathrm{~cm}_{2} \mathrm{O} \\
\text { and vital capacity of } \\
1.350 \mathrm{~mL} \text {. He was } \\
\text { transferred to the ICU } \\
\text { and intubated. He } \\
\text { remained afebrile and } \\
\text { followed commands. } \\
\text { Oxygen saturation was } \\
\text { normal on ventilator } \\
\text { settings positive end- } \\
\text { expiratory pressure } 5 \\
\mathrm{~cm} \mathrm{H}_{2} \mathrm{O} \text { and fraction of } \\
\text { inspired oxygen } 30 \% \text {. } \\
\text { Chest } \mathrm{X} \text {-ray was stable. } \\
\text { Sputum culture grew } \\
\text { Stenotrophomonas } \\
\text { maltophilia. }\end{array}$ & $\begin{array}{l}\text { Chest X-ray showed } \\
\text { mild bibasilar } \\
\text { atelectasis vs. patchy } \\
\text { consolidations. } \\
\text { Computed } \\
\text { tomography of the } \\
\text { head was normal. } \\
\text { Incompatible } \\
\text { implant precluded } \\
\text { MRI. On day 10, } \\
\text { his oropharyngeal } \\
\text { secretions increased, } \\
\text { and chest X-ray } \\
\text { showed new } \\
\text { right lower lobe } \\
\text { consolidation. }\end{array}$ & IVlg & $\begin{array}{c}\text { RT-PCR } \\
\text { and the } \\
\text { neurological } \\
\text { examination } \\
\text { disclosed } \\
\text { moderate } \\
\text { (Medical } \\
\text { Research } \\
\text { Council } \\
\text { grade 4/5). }\end{array}$ \\
\hline $\begin{array}{l}\text { Lantos } \\
\text { et al. }{ }^{20}\end{array}$ & Male & 36 & NA & $\begin{array}{l}\text { Presenting with left } \\
\text { eye drooping, blurry } \\
\text { vision, and reduced } \\
\text { sensation and } \\
\text { paresthesia in both } \\
\text { legs for } 2 \text { days. He } \\
\text { was in his usual state } \\
\text { of health until } 4 \text { days } \\
\text { before presentation, } \\
\text { when he developed } \\
\text { viral symptoms in a } \\
\text { COVID-19-endemic } \\
\text { region, reporting } \\
\text { subjective fevers, } \\
\text { chills, and myalgia. }\end{array}$ & $\begin{array}{l}\text { Physical examination } \\
\text { was notable for a } \\
\text { partial left third nerve } \\
\text { palsy and decreased } \\
\text { sensation below the } \\
\text { knees to all modalities. } \\
\text { Nonetheless, } \\
\text { the patient's } \\
\text { hospital course } \\
\text { was characterized } \\
\text { by progressive } \\
\text { ophthalmoparesis } \\
\text { (including initial left } \\
\text { CN III and eventual } \\
\text { bilateral CN VI } \\
\text { palsies), ataxia, and } \\
\text { hyporeflexia, and } \\
\text { the clinical picture } \\
\text { was thought to be } \\
\text { consistent with MFS } \\
\text { from COVID-19 } \\
\text { infection. }\end{array}$ & $\begin{array}{l}\text { Brain MRI: } \\
\text { prominent } \\
\text { enhancement with } \\
\text { gadolinium, and } \\
\text { T2 hyperintense } \\
\text { signal of the left } \\
\mathrm{CN} \text { III. No other } \\
\mathrm{CN} \text { demonstrated } \\
\text { abnormal signal. No } \\
\text { cerebellar lesions } \\
\text { were seen to explain } \\
\text { the patient's ataxia. }\end{array}$ & $\begin{array}{c}\text { IVIg; } \\
\text { hydroxychloroquine. }\end{array}$ & $\begin{array}{l}\text { RT-PCR and } \\
\text { RMI. }\end{array}$ \\
\hline
\end{tabular}


Table 1. Continuation.

\begin{tabular}{|c|c|c|c|c|c|c|c|c|}
\hline Author & Gender & Age & Comorbidities & $\begin{array}{c}\text { Clinical } \\
\text { manifestations }\end{array}$ & Patient outcome & Chest imaging & Treatment & Diagnosis \\
\hline $\begin{array}{l}\text { Camdessanche } \\
\text { et al. } .^{21}\end{array}$ & Male & 64 & NA & $\begin{array}{l}\text { The patient fell and hurt } \\
\text { his left shoulder leading } \\
\text { to a tear of the rotator } \\
\text { cuff. Eleven days after } \\
\text { the symptom onset, the } \\
\text { patient complained of } \\
\text { paresthesia in feet and } \\
\text { hands. In three days, } \\
\text { he installed a flaccid } \\
\text { severe tetraparesia. The } \\
\text { patient complained of } \\
\text { swallowing disturbance } \\
\text { with a risk of suffocation. }\end{array}$ & $\begin{array}{c}\text { Clinical presentation } \\
\text { was moderate with } \\
\text { high grade fever for } \\
\text { three days requiring } \\
\text { oxygen } 2-3 \mathrm{~L} \\
\text { min through nasal } \\
\text { cannula for five } \\
\text { days. The patient } \\
\text { was admitted in ICU } \\
\text { and mechanically } \\
\text { ventilated because } \\
\text { of respiratory } \\
\text { insufficiency. }\end{array}$ & $\begin{array}{c}\text { Thoracic CT scan } \\
\text { showed only } 10-25 \% \\
\text { of ground glass } \\
\text { opacities. }\end{array}$ & $\begin{array}{c}\text { Paracetamol, } \\
\text { preventing } \\
\text { thromboembolism } \\
\text { by low molecular } \\
\text { weight heparin and } \\
\text { LPV/RTV } 400 / 100 \\
\text { mg twice a day for } \\
\text { ten days. IVIg (0.4g/ } \\
\text { kg per day during } 5 \\
\text { days). }\end{array}$ & EMG \\
\hline $\begin{array}{l}\text { Arnaud } \\
\text { et al. } .^{22}\end{array}$ & Male & 64 & $\begin{array}{c}\text { Diabetes } \\
\text { mellitus type } 2\end{array}$ & $\begin{array}{l}\text { Cough, dyspnea, } \\
\text { diarrhea, and fever. } \\
\text { Fast progressive lower- } \\
\text { limb weakness; The } \\
\text { neurological examination } \\
\text { showed generalized } \\
\text { areflexia, severe flaccid } \\
\text { paraparesis, mainly } \\
\text { affecting proximal } \\
\text { muscles, and a decreased } \\
\text { proprioceptive length- } \\
\text { dependent sensitivity } \\
\text { involving the four } \\
\text { limbs. We also found } \\
\text { hypoesthesia to light } \\
\text { touch and pinprick in } \\
\text { lower extremities rather. }\end{array}$ & $\begin{array}{l}\text { Respiratory rate was } \\
30 \text { breaths/min and } \\
\text { oxygen saturation } \\
\text { was } 93 \% \text { on ambient } \\
\text { air. Lung auscultation } \\
\text { revealed diffuse } \\
\text { crackles. }\end{array}$ & $\begin{array}{c}\text { A chest CT showed } \\
\text { bilateral, diffuse and } \\
\text { subpleural ground- } \\
\text { glass opacities with } \\
\text { a crazy-paving } \\
\text { appearance, and a } \\
\text { band of air space } \\
\text { consolidation. }\end{array}$ & $\begin{array}{c}\text { Cefotaxime, } \\
\text { Azithromycin; } \\
\text { IVIg and } \\
\text { Hydroxychloroquine. }\end{array}$ & $\begin{array}{c}\text { RT-PCR and } \\
\text { EMG. }\end{array}$ \\
\hline \multirow[t]{2}{*}{ Bigaut et al. ${ }^{23}$} & $\begin{array}{l}\text { P1 - } \\
\text { Male }\end{array}$ & 43 & NA & $\begin{array}{l}\text { Presented with cough, } \\
\text { asthenia, and myalgia in } \\
\text { legs, followed by acute } \\
\text { anosmia and ageusia } \\
\text { with diarrhea the next } \\
\text { day. Symptoms resolved } \\
\text { spontaneously after } 2 \\
\text { weeks. Twenty-one days } \\
\text { after the beginning of } \\
\text { respiratory symptoms, } \\
\text { he presented with a } \\
\text { rapidly progressive } \\
\text { manner paraesthesia, } \\
\text { hypoesthesia, and } \\
\text { distal weakness in the } \\
\text { lower limbs. In the } \\
\text { following } 2 \text { days, these } \\
\text { symptoms extended to } \\
\text { the midthigh and tip of } \\
\text { the fingers associated } \\
\text { with ataxia, and he was } \\
\text { hospitalized at day } 4 \\
\text { due to a right peripheral } \\
\text { facial palsy. }\end{array}$ & $\begin{array}{c}\text { क } \\
\text { His BT was } 36.9^{\circ} \mathrm{C} \\
\text { and oxygen } \\
\text { saturation was } 99 \% \text {. } \\
\end{array}$ & $\begin{array}{l}\text { CT of the chest } \\
\text { showed ground-glass } \\
\text { opacities; MRI at day } \\
7 \text { showed multiple } \\
\text { cranial neuritis (in } \\
\text { nerves III, V, VI, VII, } \\
\text { and VIII), radiculitis, } \\
\text { and plexitis on both } \\
\text { the brachial and } \\
\text { lumbar plexus. }\end{array}$ & IVlg. & $\begin{array}{l}\text { RT-PCR } \\
\text { and the } \\
\text { neurological } \\
\text { examination } \\
\text { disclosed } \\
\text { moderate } \\
\text { (Medical } \\
\text { Research } \\
\text { Council } \\
\text { grade 4/5). }\end{array}$ \\
\hline & $\begin{array}{l}\text { P2 - } \\
\text { Female }\end{array}$ & 70 & Obesity & $\begin{array}{l}\text { Anosmia and } \\
\text { ageusia, followed by } \\
\text { diarrhea for } 2 \text { days. } \\
\text { She complained of } \\
\text { mild asthenia and } \\
\text { myalgia without fever. } \\
\text { Seven days later, she } \\
\text { presented with acute } \\
\text { proximal tetraparesis } \\
\text { and distal forelimb, } \\
\text { perioral dyspnea, and } \\
\text { loss of ambulation. }\end{array}$ & $\begin{array}{l}\text { Rapidly transferred to } \\
\text { an ICU for noninvasive } \\
\text { ventilation for acute } \\
\text { respiratory failure } \\
\text { with hypercapnia. She } \\
\text { was discharged from } \\
\text { the ICU } 9 \text { days later, } \\
\text { without requiring } \\
\text { invasive mechanical } \\
\text { ventilation. Her } \\
\text { clinical condition } \\
\text { improved slowly } \\
\text { with physiotherapy, } \\
\text { needing a transfer in a } \\
\text { rehabilitation center. }\end{array}$ & $\begin{array}{c}\text { CT of the chest } \\
\text { showed moderate } \\
\text { ground-glass opacities } \\
\text { in both lungs. }\end{array}$ & IVlg. & $\begin{array}{l}\text { RT-PCR } \\
\text { and the } \\
\text { neurological } \\
\text { examination } \\
\text { disclosed } \\
\text { moderate } \\
\text { (Medical } \\
\text { Research } \\
\text { Council } \\
\text { grade 4/5). }\end{array}$ \\
\hline
\end{tabular}


Table 1. Continuation.

\begin{tabular}{|c|c|c|c|c|c|c|c|c|}
\hline Author & Gender & Age & Comorbidities & $\begin{array}{c}\text { Clinical } \\
\text { manifestations }\end{array}$ & Patient outcome & Chest imaging & Treatment & Diagnosis \\
\hline $\begin{array}{l}\text { El Otmani } \\
\text { et al. } .^{24}\end{array}$ & Female & 70 & $\begin{array}{c}\text { Rheumatoid } \\
\text { arthritis }\end{array}$ & $\begin{array}{c}\text { Presented with a rapidly, } \\
\text { bilateral weakness and } \\
\text { tingling sensation in all } \\
\text { four extremities resulting } \\
\text { in a total functional } \\
\text { disability within } 48 \text { hours. } \\
\text { The patient denied any } \\
\text { sphincter disturbances, } \\
\text { dyspnea or swallowing } \\
\text { difficulties. Neurological } \\
\text { examination showed } \\
\text { quadriplegia, hypotonia, } \\
\text { areflexia, and bilateral } \\
\text { positive Lase gue sign. } \\
\text { CN were intact. Three } \\
\text { days prior to the ongoing } \\
\text { symptoms' onset, the } \\
\text { patient presented an } \\
\text { episode of dry cough } \\
\text { without dyspnea or fever, } \\
\text { spontaneously resolving } \\
\text { within } 48 \text { hours. }\end{array}$ & $\begin{array}{c}\text { Temperature, } \\
\text { lung, and cardiac } \\
\text { auscultation were also } \\
\text { normal. }\end{array}$ & $\begin{array}{l}\text { Chest CT (day 10) } \\
\text { revealed ground-glass } \\
\text { opacities in the left } \\
\text { lung. }\end{array}$ & $\begin{array}{l}\text { IVlg }(2 \mathrm{~g} / \mathrm{kg} \text { for } \\
5 \text { days }) \text { and a } \\
\text { combination of } \\
\text { Hydroxychloroquine } \\
\text { (600 mg per day) and } \\
\text { Azithromycine. }\end{array}$ & RT-PCR \\
\hline $\begin{array}{l}\text { Juliao } \\
\text { Caamaño } \\
\text { et al. }{ }^{25}\end{array}$ & Male & 61 & NA & $\begin{array}{c}\text { Fever and coughing } \\
\text { without dyspnea on } \\
\text { day } 1 \text { of the illness; } \\
\text { right peripheral facial } \\
\text { nerve palsy. }\end{array}$ & NA & $\begin{array}{l}\text { Brain CT and MRI } \\
\text { were performed } \\
\text { without any acute } \\
\text { pathological findings. }\end{array}$ & $\begin{array}{l}\text { Hydroxychloroquine } \\
\text { and LPV/RTV; oral } \\
\text { prednisone. }\end{array}$ & $\begin{array}{l}\text { X-ray and } \\
\text { RT-PCR. }\end{array}$ \\
\hline Galán et al. ${ }^{26}$ & Male & 43 & NA & $\begin{array}{l}\text { Consultation for } \\
\text { symmetric and } \\
\text { global weakness of } \\
\text { the } 4 \text { extremities of } \\
\text { progressive intensity with } \\
\text { impossibility for walking, } \\
\text { as well as alteration in } \\
\text { the sensitivity of the } 4 \\
\text { members at the distal } \\
\text { level. Three days before, } \\
\text { there was a self-limited } \\
\text { diarrhea episode, } \\
\text { followed by symptoms } \\
\text { of infection of the upper } \\
\text { respiratory tract, bilateral } \\
\text { facial paresis, and } \\
\text { dysphagia. }\end{array}$ & NA & $\begin{array}{l}\text { In the } X \text {-ray of thorax } \\
\text { there are alterations } \\
\text { suggestive of Early } \\
\text { pneumonia by } \\
\text { COVID-19. }\end{array}$ & $\begin{array}{c}\text { IVIg; sulfate } \\
\text { hydroxychloroquine, } \\
\text { antiretro virals (LPV } \\
\text { and RTV), antibiotic } \\
\text { (amoxicillin), } \\
\text { corticosteroids and } \\
\text { oxygen therapy low } \\
\text { flow. }\end{array}$ & $\begin{array}{l}\text { RT-PCR; EMG } \\
\text { and the } \\
\text { neurological } \\
\text { examination } \\
\text { disclosed } \\
\text { moderate } \\
\text { (Medical } \\
\text { Research } \\
\text { Council } \\
\text { grade 4/5). }\end{array}$ \\
\hline $\begin{array}{l}\text { Marta-Enguita } \\
\text { et al. }{ }^{27}\end{array}$ & Female & 76 & NA & $\begin{array}{l}\text { Evolution of low back } \\
\text { pain radiating to the } \\
\text { posterior aspect of both } \\
\text { legs and progressive } \\
\text { tetraparesis with } \\
\text { paresthesias of distal } \\
\text { onset. The pain was } \\
\text { bilateral, with right } \\
\text { predominance and } \\
\text { greater night intensity. } \\
\text { He associated progressive } \\
\text { weakness predominantly } \\
\text { proximal in the lower } \\
\text { extremities, and } 2 \text { days } \\
\text { before our evaluation, } \\
\text { he presented weakness } \\
\text { in the upper extremities, } \\
\text { with functional } \\
\text { limitation. Eight days } \\
\text { before the onset of } \\
\text { the symptoms, he had } \\
\text { started with a cough and } \\
\text { fever without dyspnea, } \\
\text { with } 72 \text { hours of } \\
\text { evolution; He associated } \\
\text { global areflexia } \\
\text { and hypoesthesia in } \\
\text { both legs. }\end{array}$ & $\begin{array}{l}\text { The patient was } \\
\text { admitted and at } 4 \mathrm{~h} \\
\text { presented dysphagia } \\
\text { for liquids and } \\
\text { progressively for } \\
\text { solids, with a nasal } \\
\text { voice and difficulty } \\
\text { swallowing her own } \\
\text { saliva, with progressive } \\
\text { onset of a picture of } \\
\text { ventilatory failure. She } \\
\text { presents progressive } \\
\text { deterioration, } \\
\text { requiring oxygen } \\
\text { therapy (FiO } 60 \% \text { ), } \\
\text { with maintained SatO } \\
\text { levels of around } 91 \%, \\
\text { which do not show a } \\
\text { problem of alveolar } \\
\text { capillary junction or } \\
\text { gas exchange. Finally, } \\
\text { she dies at } 12 \mathrm{~h} \text {. }\end{array}$ & $\begin{array}{l}\text { Normal cranial CT } \\
\text { and cervical spine } \\
\text { were performed, } \\
\text { showing degenerative } \\
\text { signs at the level of } \\
\text { the vertebral bodies, } \\
\text { without invasion of } \\
\text { the spinal canal. On } \\
\text { chest CT, a pattern } \\
\text { compatible with the } \\
\text { level of pulmonary } \\
\text { impairment due to } \\
\text { SARS-CoV-2 infection } \\
\text { was observed. }\end{array}$ & $\begin{array}{l}\text { NSAID, pyrazolones, } \\
\text { and transdermal } \\
\text { morphics. amoxicillin- } \\
\text { clavulanic acid, and } \\
\text { azithromycin. }\end{array}$ & RT-PCR \\
\hline
\end{tabular}


Table 1. Continuation.

\begin{tabular}{|c|c|c|c|c|c|c|c|c|}
\hline Author & Gender & Age & Comorbidities & $\begin{array}{c}\text { Clinical } \\
\text { manifestations }\end{array}$ & Patient outcome & Chest imaging & Treatment & Diagnosis \\
\hline Molina et al. ${ }^{28}$ & Female & 55 & $\begin{array}{l}\text { Dyslipemia } \\
\text { and active } \\
\text { smoking. }\end{array}$ & $\begin{array}{l}\text { Fever, unproductive } \\
\text { cough and dyspnea after } \\
15 \text { days of evolution. In } \\
\text { the past } 24 \text { hours, she } \\
\text { reported paresthesias in } \\
\text { the hands and feet, as } \\
\text { well as weakness in the } \\
\text { lower extremities. Severe } \\
\text { low back pain radiating to } \\
\text { both legs with progressive } \\
\text { weakness in the } 4 \\
\text { extremities associated } \\
\text { with dysphagia. At } \\
48 \text { hours, the patient } \\
\text { presented worsening of } \\
\text { neurological symptoms, } \\
\text { with areflexic tetraparesis. } \\
\text { Along with this, liquid } \\
\text { dysphagia, bilateral facial } \\
\text { diplegia, weakness in } \\
\text { closing the eyelids, lingual } \\
\text { and perioral paresthesias. } \\
\text { No meningeal signs. }\end{array}$ & $\begin{array}{l}\text { At initial examination, } \\
\text { the patient is conscious } \\
\text { and oriented. Blood } \\
\text { pressure } 155 / 102 \mathrm{mmH} \text {, } \\
\text { heart rate } 103 \text { beats per } \\
\text { minute, temperature } \\
36.6^{\circ} \text { C, oxygen } \\
\text { saturation } 93 \% \text { basal } \\
\text { (SatO } \mathrm{z}_{2} \text { ). Eupneic with } \\
20 \text { breaths per minute. } \\
\text { Bibasal crackles on } \\
\text { pulmonary auscultation. } \\
\text { Strength and sensitivity } \\
\text { preserved in the } 4 \\
\text { limbs. Rest of physical } \\
\text { examination without } \\
\text { significant changes. } \\
\text { Adequate ventilatory } \\
\text { mechanics and SatO2 } \\
\text { without the need for } \\
\text { respiratory support. } \\
\text { In this context, it was } \\
\text { decided to transfer to } \\
\text { the ICU. }\end{array}$ & $\begin{array}{l}\text { Chest radiography } \\
\text { revealed consolidation } \\
\text { in the left lower } \\
\text { lobe; Using MRI, a } \\
\text { slight leptomeningeal } \\
\text { improvement is } \\
\text { observed in the brain } \\
\text { stem and cervical cord. }\end{array}$ & $\begin{array}{l}\text { hydroxychloroquine, } \\
\text { ceftriaxone and } \\
\text { azithromycin; IVlg. }\end{array}$ & $\begin{array}{l}\text { RT-PCR } \\
\text { and the } \\
\text { neurological } \\
\text { examination } \\
\text { disclosed } \\
\text { moderate } \\
\text { (Medical } \\
\text { Research } \\
\text { Council } \\
\text { grade 4/5). }\end{array}$ \\
\hline $\begin{array}{l}\text { Sancho- } \\
\text { Saldaña } \\
\text { et al. }{ }^{29}\end{array}$ & Female & 56 & NA & $\begin{array}{l}\text { Recent unsteadiness } \\
\text { and paraesthesia in } \\
\text { both hands. Fifteen days } \\
\text { earlier, she had reported } \\
\text { fever, dry cough, and } \\
\text { shortness of breath that } \\
\text { was controlled with } \\
\text { symptomatic treatment. } \\
\text { she developed lumbar } \\
\text { pain and progressive } \\
\text { proximal lower limb } \\
\text { weakness, bilateral } \\
\text { facial nerve palsy, } \\
\text { oropharyngeal weakness, } \\
\text { and severe proximal } \\
\text { tetraparesis with cervical } \\
\text { flexion. }\end{array}$ & $\begin{array}{l}\text { She was transferred } \\
\text { to the ICU for } 5 \\
\text { days due to the } \\
\text { risk of respiratory } \\
\text { insufficiency and began } \\
\text { rehabilitation, not } \\
\text { needing mechanical } \\
\text { ventilation. She started } \\
\text { recovering by day } \\
7 \text { after the onset of } \\
\text { weakness. }\end{array}$ & $\begin{array}{l}\text { Her chest X-ray } \\
\text { showed a lobar } \\
\text { consolidation. }\end{array}$ & $\begin{array}{l}\text { hydroxychloroquine } \\
\text { and azithromycin; } \\
\text { IVlg. }\end{array}$ & $\begin{array}{l}\text { RT-PCR } \\
\text { and the } \\
\text { neurological } \\
\text { examination } \\
\text { disclosed } \\
\text { moderate } \\
\text { (Medical } \\
\text { Research } \\
\text { Council } \\
\text { grade 4/5). }\end{array}$ \\
\hline $\begin{array}{l}\text { Reyes-Bueno } \\
\text { et al. }{ }^{30}\end{array}$ & Female & 51 & NA & $\begin{array}{l}\text { Diarrhea, odynophagia, } \\
\text { and cough. The } \\
\text { condition lasted } \\
\text { approximately } 10 \text { days, } \\
\text { after which she kept } \\
\text { feeling discomfort in the } \\
\text { throat. She did not refer } \\
\text { ageusia or anosmia. }\end{array}$ & $\begin{array}{l}\text { From March } 30^{\text {th }} \text {, } \\
\text { she started having } \\
\text { intense root-type } \\
\text { pain in all four limbs, } \\
\text { especially in the legs } \\
\text { as well as dorsal and } \\
\text { lumbar back pain. On } \\
\text { April } 4^{\text {hh }} \text { she started } \\
\text { with weakness in her } \\
\text { lower limbs, which } \\
\text { progressed to the point } \\
\text { of preventing her from } \\
\text { walking in a few days, } \\
\text { associated with double } \\
\text { binocular vision. The } \\
\text { neurological exploration } \\
\text { showed paresis of the } \\
\text { left external rectus } \\
\text { muscle with horizontal } \\
\text { diplopia when looking } \\
\text { to the left, discrete } \\
\text { predominantly } \\
\text { inferior bilateral facial } \\
\text { paresis, symmetrical } \\
\text { paraparesis with } 3+/ 5 \\
\text { weakness in psoas, } \\
\text { hamstrings, gluteus, } \\
\text { and quadriceps, } 3 / 5 \\
\text { in gastrocnemius, } 2 / 5 \\
\text { in posterior tibial and } \\
\text { peroneal; and global } \\
\text { areflexia. She also } \\
\text { presented symptoms of } \\
\text { autonomic dysfunction } \\
\text { such as dry mouth, } \\
\text { diarrhea, and unstable } \\
\text { blood pressure. }\end{array}$ & NA & IVlg. & $\begin{array}{c}\text { RT-PCR } \\
\text { and ELISA } \\
\text { technique; } \\
\text { the } \\
\text { neurological } \\
\text { examination } \\
\text { disclosed } \\
\text { moderate } \\
\text { (Medical } \\
\text { Research } \\
\text { Council } \\
\text { grade 4/5). }\end{array}$ \\
\hline
\end{tabular}


Table 1. Continuation.

\begin{tabular}{|c|c|c|c|c|c|c|c|c|}
\hline Author & Gender & Age & Comorbidities & $\begin{array}{c}\text { Clinical } \\
\text { manifestations }\end{array}$ & Patient outcome & Chest imaging & Treatment & Diagnosis \\
\hline $\begin{array}{l}\text { Chan } \\
\text { et al. }{ }^{31}\end{array}$ & Male & 58 & NA & $\begin{array}{l}\text { Presented with } \\
\text { acute-onset } \\
\text { bilateral facial } \\
\text { weakness, } \\
\text { dysarthria, and } \\
\text { paresthesia in his } \\
\text { feet. He denied any } \\
\text { other neurological } \\
\text { symptoms, } \\
\text { including anosmia } \\
\text { and ageusia. He } \\
\text { denied fever, } \\
\text { fatigue, cough, } \\
\text { shortness of } \\
\text { breath, or any } \\
\text { other symptoms on } \\
\text { review of systems. } \\
\text { Neurological } \\
\text { examination } \\
\text { demonstrated } \\
\text { complete facial } \\
\text { diplegia and } \\
\text { areflexia in the } \\
\text { lower extremities. } \\
\text { he had slight } \\
\text { movements of } \\
\text { his facial muscles } \\
\text { and the distal } \\
\text { paresthesias of his } \\
\text { lower extremities } \\
\text { were unchanged. }\end{array}$ & $\begin{array}{c}\text { Temperature of } \\
36.6^{\circ} \mathrm{C} \text {, maximum } \\
\text { heart rate of } 140 \\
\text { beats/minute, } \\
\text { maximum blood } \\
\text { pressure of } \\
187 / 103 \text { mmHg, } \\
\text { maximum } \\
\text { respiratory rate } \\
\text { of } 34 \text { breaths/ } \\
\text { minute, and an } \\
\text { oxygen saturation } \\
\text { of } 96 \% \text { on } \\
\text { room air, with } \\
\text { resolution of } \\
\text { tachycardia, } \\
\text { hypertension, } \\
\text { and tachypnea } \\
\text { within } 12 \text { hours. } \\
\text { Auscultation of } \\
\text { the lungs revealed } \\
\text { diffuse crackles } \\
\text { bilaterally. }\end{array}$ & $\begin{array}{l}\text { Chest x-ray } \\
\text { demonstrated } \\
\text { diffuse } \\
\text { heterogeneous } \\
\text { infiltration in both } \\
\text { lungs. CT and } \\
\text { CTA of the head } \\
\text { and neck did } \\
\text { not demonstrate } \\
\text { any intracranial } \\
\text { or vascular } \\
\text { abnormalities but } \\
\text { demonstrated } \\
\text { ground-glass } \\
\text { opacities in both } \\
\text { lung apices. }\end{array}$ & $\begin{array}{c}\text { Empiric } \\
\text { ceftriaxone and } \\
\text { azithromycin; } \\
\text { IVIg. }\end{array}$ & $\begin{array}{l}\text { RT-PCR } \\
\text { and } \\
\text { EMG; }\end{array}$ \\
\hline $\begin{array}{l}\text { Coen } \\
\text { et al. }{ }^{32}\end{array}$ & Male & 70 & NA & $\begin{array}{l}\text { Paraparesis, } \\
\text { distal allodynia, } \\
\text { difficulties in } \\
\text { voiding and } \\
\text { constipation. } \\
\text { Ten days before } \\
\text { he developed } \\
\text { myalgia, fatigue, } \\
\text { and a dry cough. }\end{array}$ & $\begin{array}{l}\text { Physical } \\
\text { examination } \\
\text { revealed fine } \\
\text { crackles in the } \\
\text { left base, bilateral } \\
\text { lower limb } \\
\text { flaccid paresis, } \\
\text { absent deep } \\
\text { tendon reflexes } \\
\text { of the upper and } \\
\text { lower limb and } \\
\text { idiomuscular } \\
\text { response to } \\
\text { percussion of } \\
\text { the muscle } \\
\text { tibialis anterior, } \\
\text { indifferent plantar } \\
\text { reflexes. There } \\
\text { was no sensory } \\
\text { deficit.FilmArray } \\
\text { Meningitis/ } \\
\text { Encephalitis } \\
\text { (ME) Panel } \\
\text { testing (BioFire } \\
\text { Diagnostics, Salt } \\
\text { Lake City, UT) and } \\
\text { SARS-CoV-2 RT- } \\
\text { PCR were negative. } \\
\text { showed decreased } \\
\text { persistence or } \\
\text { absent F-waves in } \\
\text { tested nerves. }\end{array}$ & $\begin{array}{l}\text { Chest X-ray was } \\
\text { normal. Contrast- } \\
\text { enhanced } \\
\text { MRI excluded } \\
\text { myelopathy. } \\
\text { Nerve conduction } \\
\text { study showed } \\
\text { sensorimotor } \\
\text { demyelinating } \\
\text { polyneuropathy } \\
\text { with "sural } \\
\text { sparing pattern"; } \\
\text { F wave study } \\
\text { showed } \\
\text { decreased } \\
\text { persistence or } \\
\text { absent F-waves in } \\
\text { tested nerves. }\end{array}$ & IVlg. & $\begin{array}{c}\text { RT-PCR } \\
\text { and ELISA } \\
\text { technique. }\end{array}$ \\
\hline
\end{tabular}


Table 1. Continuation.

\begin{tabular}{|c|c|c|c|c|c|c|c|c|}
\hline Author & Gender & Age & Comorbidities & $\begin{array}{c}\text { Clinical } \\
\text { manifestations }\end{array}$ & Patient outcome & Chest imaging & Treatment & Diagnosis \\
\hline \multirow{3}{*}{$\begin{array}{l}\text { Lascano } \\
\text { et al. }{ }^{33}\end{array}$} & $\begin{array}{l}\text { P1 - } \\
\text { Female }\end{array}$ & 52 & NA & $\begin{array}{c}\text { Dry cough, fever, } \\
\text { odynophagia, } \\
\text { arthralgia, diarrhoea. } \\
\text { Back pain, limb } \\
\text { weakness, ataxia, } \\
\text { distal paresthesia, } \\
\text { dysgeusia, cacosmia. } \\
\text { Developed respiratory } \\
\text { failure, dysautonomia, } \\
\text { and tetraplegia with } \\
\text { areflexia. }\end{array}$ & $\begin{array}{l}\text { Improvement of } \\
\text { tetraparesis. Able } \\
\text { to stand up with } \\
\text { assistance. GBS } \\
\text { disability clinical } \\
\text { score } 4 / 6 . \\
\text { Spinal cord: } \\
\text { no nerve root } \\
\text { gadolinium } \\
\text { enhancement. }\end{array}$ & NA & IVlg & $\begin{array}{c}\text { RT-PCR and } \\
\text { Antibodies } \\
\text { for SARS- } \\
\text { CoV-2 IgM/ } \\
\text { lgG. }\end{array}$ \\
\hline & $\begin{array}{l}\text { P2 - } \\
\text { Female }\end{array}$ & 63 & $\begin{array}{c}\text { Diabetes } \\
\text { mellitus } \\
\text { type } 2\end{array}$ & $\begin{array}{l}\text { Dry cough, shivering, } \\
\text { odynophagia, } \\
\text { breathing difficulties, } \\
\text { chest pain. Lower } \\
\text { limb pain, mild } \\
\text { weakness and } \\
\text { normal deep tendon } \\
\text { reflexes. Developed } \\
\text { tetraparesis, distal } \\
\text { paresthesia and } \\
\text { areflexia. }\end{array}$ & $\begin{array}{l}\text { Dismissal with full } \\
\text { motor recovery. } \\
\text { Persistence of lower } \\
\text { limb areflexia and } \\
\text { distal paresthesia. } \\
\text { GBS disability } \\
\text { clinical score 1/6. }\end{array}$ & NA & IVlg & RT-PCR \\
\hline & $\begin{array}{l}\text { P3 - } \\
\text { Female }\end{array}$ & 61 & NA & $\begin{array}{l}\text { Productive cough, } \\
\text { fever, myalgia, } \\
\text { vasovagal syncope, } \\
\text { diarrhoea, nausea } \\
\text { and vomiting. Lower } \\
\text { limb weakness and } \\
\text { distal paresthesia, } \\
\text { dizziness, dysphagia, } \\
\text { dysautonomia, } \\
\text { areflexia. Presented } \\
\text { worsening of bulbar } \\
\text { symptoms and } \\
\text { bilateral facial palsy. }\end{array}$ & $\begin{array}{l}\text { Improvement of } \\
\text { tetraparesis and } \\
\text { ability to walk } \\
\text { with assistance. } \\
\text { Persistence of } \\
\text { neuropathic } \\
\text { pain and distal } \\
\text { paresthesia. GBS } \\
\text { disability clinical } \\
\text { score } 3 / 6 \text {. Spinal } \\
\text { cord: lumbosacral } \\
\text { nerve root } \\
\text { enhancement. } \\
\text { Normal brain } \\
\text { imaging. }\end{array}$ & NA & IVlg & RT-PCR \\
\hline $\begin{array}{l}\text { Helbok } \\
\text { et al. } .^{34}\end{array}$ & Male & 68 & NA & $\begin{array}{l}\text { Cough, headache, } \\
\text { fatigue, myalgia and } \\
\text { fever up to } 39^{\circ} \mathrm{C} \\
\text { followed by anosmia } \\
\text { and ageusia. but } \\
\text { still complained of } \\
\text { severe fatigue and } \\
\text { developed symmetric } \\
\text { distal tingling in } \\
\text { both feet followed } \\
\text { by ascending } \\
\text { dysesthesias up } \\
\text { to the knees and } \\
\text { proximal weakness. }\end{array}$ & $\begin{array}{l}\text { His respiratory } \\
\text { condition worsened, } \\
\text { and the patient } \\
\text { required oxygen } \\
\text { supplementation } \\
\text { (3L/min) followed } \\
\text { by pressure support } \\
\text { non-invasive } \\
\text { ventilation after } \\
36 \text { h. The next } \\
\text { day he presented } \\
\text { inability to walk. On } \\
\text { examination, the } \\
\text { patient was alert } \\
\text { and fully oriented, } \\
\text { afebrile with } \\
\text { normal vital signs } \\
\text { (oxygen saturation } \\
98 \% \text { on room air, } \\
\text { blood pressure } \\
143 / 90 m m \text { m }, \text { heat } \\
\text { rate } 85 \text { bpm). Due } \\
\text { to muscle weakness } \\
\text { accompanied } \\
\text { by respiratory } \\
\text { failure the patient } \\
\text { underwent elective } \\
\text { intubation in a fully } \\
\text { conscious state. }\end{array}$ & $\begin{array}{l}\text { Chest Computed } \\
\text { tomography was } \\
\text { performed and } \\
\text { revealed residual } \\
\text { ground-glass } \\
\text { opacities in both } \\
\text { lower lungs }\end{array}$ & $\begin{array}{l}\text { IVIg and plasma } \\
\text { exchange }\end{array}$ & $\begin{array}{l}\text { RT-PCR and } \\
\text { Antibodies } \\
\text { for SARS- } \\
\text { CoV-2 IgM/ } \\
\text { IgG; the } \\
\text { neurological } \\
\text { examination } \\
\text { disclosed } \\
\text { moderate } \\
\text { (Medical } \\
\text { Research } \\
\text { Council } \\
\text { grade 4/5). }\end{array}$ \\
\hline
\end{tabular}


Table 1. Continuation.

\begin{tabular}{|c|c|c|c|c|c|c|c|c|}
\hline Author & Gender & Age & Comorbidities & $\begin{array}{c}\text { Clinical } \\
\text { manifestations }\end{array}$ & Patient outcome & Chest imaging & Treatment & Diagnosis \\
\hline $\begin{array}{l}\text { Kilinc } \\
\text { et al. }{ }^{35}\end{array}$ & Male & 50 & NA & $\begin{array}{l}\text { Four days of } \\
\text { progressive bilateral } \\
\text { facial weakness, } \\
\text { paresthesia of distal } \\
\text { extremities and an } \\
\text { unsteady gait. Four } \\
\text { weeks earlier he } \\
\text { had experienced } \\
\text { an episode of } \\
\text { dry cough lasting } \\
\text { several days } \\
\text { without fever or } \\
\text { other symptoms of } \\
\text { infection. Neurologic } \\
\text { examination } \\
\text { showed facial } \\
\text { diplegia, normal eye } \\
\text { movements, mild } \\
\text { symmetric proximal } \\
\text { muscle weakness } \\
\text { and impaired } \\
\text { propriocepsis in the } \\
\text { legs. Patient had } \\
\text { an ataxic gait and } \\
\text { tendon reflexes } \\
\text { were absent. }\end{array}$ & $\begin{array}{l}\text { Routine blood } \\
\text { examination } \\
\text { showed no } \\
\text { abnormalities. } \\
\text { Routine analysis } \\
\text { of CSF showed a } \\
\text { normal cell count } \\
\text { and total protein } \\
\text { level. }\end{array}$ & & & $\begin{array}{l}\text { RT-PCR } \\
\text { and } \\
\text { Antibodies } \\
\text { for SARS- } \\
\text { CoV-2 } \\
\text { IgM/lgG; } \\
\text { EMG. }\end{array}$ \\
\hline $\begin{array}{l}\text { Oguz- } \\
\text { Akarsu } \\
\text { et al. }{ }^{36}\end{array}$ & Female & 53 & NA & $\begin{array}{l}\text { History of dysarthria } \\
\text { associated with } \\
\text { progressive } \\
\text { weakness and } \\
\text { numbness of the } \\
\text { lower extremities. } \\
\text { She had a mild } \\
\text { fever }\left(37.5^{\circ} \mathrm{C}\right) \text { but } \\
\text { no cough, dyspnea, } \\
\text { anosmia or ageusia. }\end{array}$ & NA & $\begin{array}{l}\text { Focal intensities } \\
\text { suspicious for } \\
\text { COVID-19 } \\
\text { pneumonia } \\
\text { were incidentally } \\
\text { identified in } \\
\text { peripheral areas } \\
\text { of lungs on STIR } \\
\text { sequence of the } \\
\text { brachial plexus MRI; } \\
\text { Chest computed } \\
\text { tomography } \\
\text { showed bilateral } \\
\text { peripheral ground- } \\
\text { glass opacities and } \\
\text { consolidations on } \\
\text { both lungs. }\end{array}$ & $\begin{array}{l}\text { Plasma exchange; } \\
\text { hydroxychloroquine } \\
\text { and azithromycin. }\end{array}$ & RT-PCR \\
\hline $\begin{array}{l}\text { Scheidl } \\
\text { et al. }{ }^{37}\end{array}$ & Female & 54 & NA & $\begin{array}{l}\text { Areflexia, numbness, } \\
\text { and tingling of all } \\
\text { extremities were } \\
\text { also found, with } \\
\text { initial maintained } \\
\text { gain ability. She } \\
\text { did not experience } \\
\text { fever, respiratory } \\
\text { or gastrointestinal } \\
\text { symptoms, but } \\
\text { reported about a } \\
\text { transient loss of smell } \\
\text { and taste } 2 \text { weeks } \\
\text { before the GBS } \\
\text { symptoms occurred. }\end{array}$ & $\begin{array}{l}\text { The first } \\
\text { electrophysiological } \\
\text { evaluation (at } \\
\text { admission) showed } \\
\text { significantly } \\
\text { prolonged distal } \\
\text { motor latencies } \\
\text { and temporal } \\
\text { dispersion of the } \\
\text { CMAP of the } \\
\text { common peroneal } \\
\text { nerve bilaterally. }\end{array}$ & $\begin{array}{l}\text { MRI of the } \\
\text { cervical spine } \\
\text { and the chest } \\
\text { x-ray examination } \\
\text { did not show } \\
\text { pathological } \\
\text { findings. } \\
\text { Electrophysiological } \\
\text { studies were } \\
\text { performed using } \\
\text { a Nicolet Viking } \\
\text { EMG device. }\end{array}$ & IVlg & $\begin{array}{c}\text { RT-PCR } \\
\text { and EMG. }\end{array}$ \\
\hline
\end{tabular}

LPV: lopinavir; RTV: ritonavir; RT-PCR: real-time reverse transcriptase; CT: chest tomography; EMG: electromyography; NA: Not Applicable; CRP: C-reactive protein; LDH: lactate dehydrogenase; IVIg: intravenous immune globulin; AST: aspartate aminotransferase; MRI: magnetic resonance imaging; GGT: gamaglutamiltranspeptidase; ICU: intensive care unit; BT: body temperature; CN: cranial nerve; MFS: Miller Fisher Syndrome; NSAID: non-steroidal anti-inflammatory drugs; ELISA: enzyme-linked immunosorbent assay; CTA: CT angiography; GBS: Guillain-Barre Syndrome; CSF: cerebrospinal fluid; STIR: Short-Tau Inversion Recovery; CMAP: compound muscle action potentials. 
Case Reports ${ }^{9}$, that is, they achieved a high score and, thusly, were included in the review.

\section{Synthesis of results}

\section{Clinical manifestations}

Main clinical manifestations were fever, coughing, dyspnea, sore throat, ageusia, anosmia, respiratory failure, and diarrhea, as shown in Figure 2.

Toscano et al. ${ }^{10}$ describing three patients [P1, P3, and P5] who received mechanical ventilation and two who were admitted to the Intensive Care Unit (ICU) [P3 and P5]. The condition of $\mathrm{P} 5$ deteriorates during hospitalization, presentation of hypercapnia, paradoxical breathing, and acidosis, leading to admission to the ICU, where mechanical ventilation by tracheostomy and pneumonia by acinetobacter is allowed.

Alberti et al. ${ }^{12}$ describing a patient with hemodynamic disorders with severe drug-resistant hypertension and arterial blood gases indicate severe hypoxia.

Assini et al. ${ }^{13}$ described a patient who needs tracheostomy and assisted ventilation [P2].

Ottaviani et al. ${ }^{14}$ described a patient who was treated for organ failure, in addition to deep venous thrombosis of the legs and overlapping bacterial infection (pneumonia ab ingestis).

Rana et al. ${ }^{18}$ described a patient who developed persistent difficulty in urinating, or who ended up requiring a permanent catheter.

Su et al. ${ }^{19}$ described a patient who had a sputum culture Stenotrophomonas maltophilia, an organism associated with pneumonia associated with mechanical ventilation.

However, Chan et al. ${ }^{31}$ described an asymptomatic patient. In addition, other patients require ventilatory support $^{11-14,16,17,19,21,23,27,29,34}$, five need intubation ${ }^{11,14,18,19,34}$, and eight were admitted to the ICU ${ }^{11,13,14,17,19,21,23,29}$. However, two ${ }^{12,27}$ of the twenty-nine patients died during treatment from progressive respiratory failure.

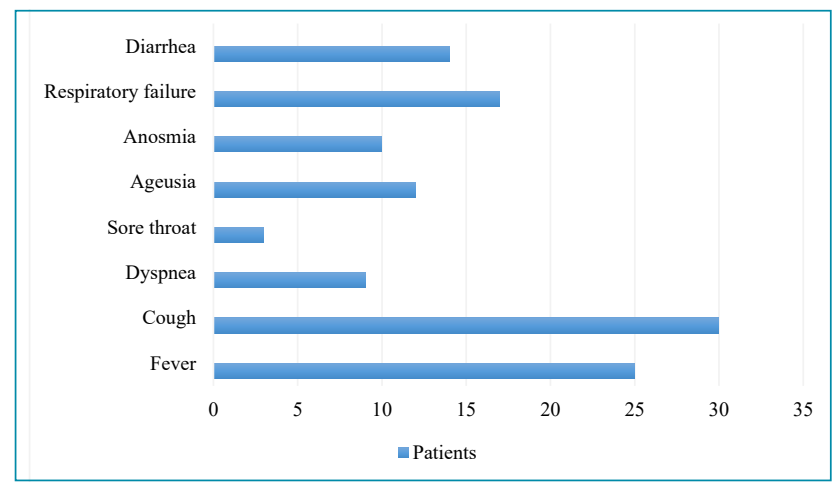

Figure 2. Prevalence of symptoms.

\section{Diagnosis}

The main methods for diagnosing SARS-Cov-2 infection (COVID-19) were nasopharyngeal swabs for polymerase chain reaction with real-time reverse transcriptase (RT-PCR), enzyme-linked immunosorbent assay (ELISA) technique, chest radiography, chest tomography $(\mathrm{CT})$, and clinical examination ${ }^{1,10-37}$.

Sixteen studies used CT and RT-PCR in the chest ${ }^{1,10-14,16,17,21-}$ 25,27,36,37; six studies used chest radiography and RT-PCR ${ }^{17-19,26,28,29}$; five studies used only RT-PCR ${ }^{20,31-33,37}$; two studies used the ELISA and CT technique ${ }^{15,34}$; and two studies used only the ELISA technique ${ }^{30,35}$.

Electromyography and clinical methods were used for the diagnosis of GBS ${ }^{1,10-37}$, with strong muscle evaluation using the Medical Research Council (MRC) 1,10,12,14-16,18,19,21,23,26,29,34,36.

\section{Treatment}

The main treatment methods mentioned were empirical antibiotics ${ }^{1,10,16-18,21,22,24,26-29,31,36}$; Hydroxychloroquine e $^{1,12-14,16,18,20,22-26,28,29,36}$; antivirals (lopinavir and ritonavir) 1,10,12-14,21,25,26; room isolation $^{10,16}$; and plasma exchange $e^{17,34,36}$. Thirty-six patients were treated with intravenous immunoglobulin (IVIg) ${ }^{1,10-24,26,28-35,37}$.

\section{Neurological outcome}

The main neurological manifestations were: weakness in the lower extremities $^{1,10,12,14-18,22-24,29,30,33,35}$; paresthesia of the upper and lower limbs ${ }^{11,12,15,17-19,21,23,24,28,29,31,33-35,37}$; tetraparesis ${ }^{1,12,17,21,23,27-29,33}$; facial diplegia ${ }^{1,14,17,23,25,26,28-31,33,35}$; areflexia ${ }^{10,17,18,22,24,27,30,31,33}$; asthenia $^{11,17,23}$; mastoid pain and sensitive ataxia ${ }^{17}$; fatigue ${ }^{10,14,32,34}$; numbness ${ }^{16,18,36,37}$; swallowing disorders ${ }^{21,26-28,33}$; low back pain ${ }^{12,27-29}$; difficulty or loss in walking ${ }^{14,23,26,30,35}$; myalgia ${ }^{15,20,23,30,32-34}$; odynophagia $^{18,30,33}$; hypoesthesia ${ }^{22,23,27}$; paraparesis ${ }^{22,30,32}$; dysarthria ${ }^{31,36}$; hyporeflexia ${ }^{13,20}$; bilateral eyelid ptosis ${ }^{13}$; progressive ophthalmoparesis ${ }^{20}$; desesthesia ${ }^{14,34}$; dysgeusia, cacosmia, disautonomy, arthralgia, and tetraplegia ${ }^{33}$.

\section{Patient outcomes}

Main patient outcomes were:

- Only nine studies revealed comorbidities, type 2 diabetes mellitus ${ }^{1,22,33}$; hypertension, abdominal aortic aneurysm and lung cancer ${ }^{12}$; obesity ${ }^{23}$; dyslipidemia and active smoking ${ }^{28}$; rheumatoid arthritis ${ }^{24}$; hypertension, hyperlipidemia, restless legs syndrome, and back pain ${ }^{18}$; and coronary artery disease, hypertension, and alcohol ${ }^{19}$;

- Patients with lymphopenia ${ }^{10,13,17,28,33,36}$;

- Images showing multiple opacities in the ground glass ${ }^{1,10-}$ $12,14-17,19-24,26,28,29,31,34,36$ or inflammation in the lungs and a small amount of pleural effusion ${ }^{1,17}$; 
- Muscle strength testing showed failure in four limbs

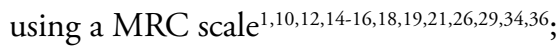

- Hospitalizations in ICU $\mathrm{U}^{11,13,14,17,19,21,29}$ and patients with advanced support for mechanical ventilation of the airways $^{11-14,16,19,21,23,27,29,34}$;

- Patients undergoing physical therapy for rehabilitation ${ }^{16-18,23}$;

- Lung auscultation revealed diffuse rales ${ }^{22}$;

- Cases presenting variant forms of GBS, such as acute sensory-motor neuropathy, acute axonal neuropathy, and Miller-Fisher syndrome ${ }^{1,13,25,30}$.

\section{DISCUSSION}

Until now, little is known about the neurological manifestations from COVID-19 and its direct relationship with GBS. The first case where neurological characteristics were observed standing out from the COVID-19 clinical symptoms was recently described; main symptoms included acute weakness in the legs and severe fatigue, with rapid progression ${ }^{10}$. For this reason, there are concerns that this virus is a possible trigger for GBS.

Sedaghat \& Karimi ${ }^{1}$, in one case report, described GBS for the first time in a patient infected with COVID-19. The patient reported acute progressive symmetric ascending quadriparesis. Two weeks before hospitalization, the patient suffered from cough, fever, and RT-PCR was reported positive for COVID19 infection. The electrodiagnostic test showed that the patient had an Acute Motor-Sensory Axonal Neuropathy (AMSAN) variant of GBS.

In the study carried out by Toscano et al. ${ }^{10}$, five patients with GBS after the onset of Covid-19 were examined. The first symptoms were lower-limb weakness and paresthesia in four patients and facial diplegia, followed by ataxia and paresthesia in one patient. In summary, flaccid tetraparesis or tetraplegia evolved from 36 hours to 4 days in four patients; three received mechanical ventilation. The interval between the onset of symptoms of Covid-19 and the first symptoms of GBS ranged from 5 to 10 days. This interval is similar that seen with GBS that occurs during or after other infections. As in previous studies, the authors point out that a possible relationship between these two diseases is the fact that COVID-19 through stimulation of inflammatory cells produces various inflammatory cytokines, and as a result, creates immune-mediated processes. As the GBS is an immune-mediated disorder, molecular mimicry as a mechanism of autoimmune disorder plays a vital role in its creation.

Zhao et al. ${ }^{16}$ reported a woman who presented with acute weakness in both legs and severe fatigue, progressing within one day. Neurological examination disclosed symmetric weakness and areflexia in both legs and feet. Three days after admission, her symptoms progressed. Oropharyngeal swabs were positive for SARS-CoV-2 with RT-PCR assay. Considering the temporal association, it was speculated that the SARS$\mathrm{CoV}-2$ infection might have been responsible for the development of GBS.

Virani et al. ${ }^{17}$, in their study, described a case where the patient with COVID-19 presented neurological symptoms, including numbness and weakness of the extremities; consequently, there was a decrease in tendon reflexes with rapid progression. The mechanism proposed for this association is an autoimmune reaction where antibodies to surface glycoproteins are developed in the offending pathogen that also corresponds to similar protein structures of peripheral nerve components (molecular mimicry), leading to neurologic involvement.

Camdessanche et al. ${ }^{21}$, in their study, also reported on one patient without medical history who was admitted after he fell and hurt the left shoulder, leading to a tear of the rotator cuff. He had a fever and cough for two days. SARS-CoV-2 RT-PCR with nasopharyngeal swab was performed and proved to be positive. Eleven days after symptom onset, the patient complained of paresthesia in both feet and hands. In three days, he demonstrated severe flaccid tetraparesis. The patient complained of swallowing disturbance with a risk of suffocation as liquids took the wrong path. The patient was admitted to ICU and mechanically ventilated due to respiratory insufficiency.

Padroni et al. ${ }^{11}$ described a case of GBS following a clinically resolved paucisymptomatic COVID-19. The patient complained of asthenia, hands, and feet paresthesia, and gait difficulties, progressing within one day. Symptoms of COVID19 were resolved in a few days. Neurological examination disclosed moderate symmetric distal upper and lower limb weakness, loss of deep tendon reflexes, preserved light touch, and pinpricking sensation.

Assini et al. ${ }^{13}$ described two cases of GBS and COVID19. In one of them, the patient needed invasive ventilation in the ICU and had an acute onset of bilateral eyelid ptosis, dysphonia, and dysphalgia 20 days after admission. Furthermore, through neurological examination, he demonstrated a deficit in the protrusion of the tongue due to bilateral paralysis of the hypoglossal nerve and hyporeflexia of the upper and lower limbs, along with bilateral masseter weakness.

Putting together all of these findings, the causal association between GBS and COVID-19 remains speculative but very probable. Neurologists and other clinicians should be aware of the essential early recognition and treatment of the potential neuromuscular and autonomic worsening leading to cardio-respiratory failure in patients with GBS and mild or controlled pulmonary COVID-19. More in-depth research should be 
carried out about this association, so that there is an established protocol of suitable diagnosis and treatment, in order to avoid high degrees of debilitation caused by GBS.

\section{Limitations}

The main limitation of this review was the lack of studies with a larger number of patients.

\section{CONCLUSION}

In conclusion, through well-designed primary studies, it is evident that COVID-19 can trigger GBS, as patients had clinical manifestations of COVID-19 infection and neurological manifestations characterizing GBS. Although the small number of patients limited our estimates, we believe that the results listed here are important for a better diagnosis and treatment of patients with neurological symptoms concomitant with respiratory symptoms

\section{AUTHORS' CONTRIBUTIONS}

KSM: Conceptualization, Data Curation, Formal Analysis, Supervision, Writing - Original Draft, Writing - Review \& Editing. LTAM: Conceptualization, Data Curation, Formal Analysis, Writing - Original Draft. ACS: Conceptualization, Formal Analysis, Writing - Original Draft. WFS: Data Curation, Formal Analysis. AKG: Supervision, Writing - Review \& Editing. APF: Writing - Review \& Editing.

\section{REFERENCES}

1. Sedaghat Z, Karimi N. Guillain Barre syndrome associated with COVID-19 infection: a case report. J Clin Neurosci. 2020;76:233-5. https://doi.org/10.1016/j.jocn.2020.04.062

2. Sejvar JJ, Baughman AL, Wise M, Morgan OW. Population incidence of Guillain-Barré syndrome: a systematic review and meta-analysis. Neuroepidemiology. 2011;36(2):123-33. https://doi.org/10.1159/000324710

3. Huang X, Wei F, Hu L, Wen L, Chen K. Epidemiology and clinical characteristics of COVID-19. Arch Iran Med. 2020;23(4):26871. https://doi.org/10.34172/aim.2020.09

4. Wu Y, Xu X, Chen Z, Duan J, Hashimoto K, Yang L, et al. Nervous system involvement after infection with COVID-19 and other coronaviruses. Brain Behav Immun. 2020;87:18-22. https://doi.org/10.1016/j.bbi.2020.03.031

5. Tricco AC, Lillie E, Zarin W, O'Brien KK, Colquhoun H, Levac $D$, et al. PRISMA Extension for Scoping Reviews (PRISMA-SCR): checklist and explanation. Ann Intern Med. 2018;169(7):46773. https://doi.org/10.7326/M18-0850

6. Huang $C$, Wang $Y$, Li X, Ren L, Zhao J, Hu Y, et al. Clinical features of patients infected with 2019 novel coronavirus in Wuhan, China. Lancet. 2020;395(10223):497-506. https:// doi.org/10.1016/S0140-6736(20)30183-5

7. Joanna Briggs Institute. Levels of evidence: developed by the Joanna Briggs Institute. Levels of evidence and grades of recommendation working part. Adelaide: The Joanna Briggs Institute; 2013. [cited on Aug. 01, 2020]. Available from: https://joannabriggs.org/sites/default/files/2019-05/ JBI-Levels-of-evidence_2014_0.pdf

8. Joanna Briggs Institute. The Joanna Briggs Institute critical appraisal tools for use in JBI systematic reviews checklist for case series. Adelaide: The Joanna Briggs Institute. [cited on Aug. 01, 2020]. Available from: http://joannabriggs.org/ research/critical-appraisal-tools.html

9. Joanna Briggs Institute. The Joanna Briggs Institute critical appraisal tools for use in JBI systematic reviews checklist for case reports. Adelaide: The Joanna Briggs Institute. [cited on Aug. 01, 2020]. Available from: https://joannabriggs.org/ research/critical-appraisal-tools.html
10. Toscano G, Palmerini F, Ravaglia S, Ruiz L, Invernizzi P, Cuzzoni MG. Guillain-Barré syndrome associated with SARS-CoV-2. N Engl J Med. 2020;382(26):2574-6. https://doi.org/10.1056/ NEJMc2009191

11. Padroni M, Mastrangelo V, Asioli GM, Pavolucci L, Abu-Rumeileh S, Piscaglia MG, et al. Guillain-Barré syndrome following COVID-19: new infection, old complication? J Neurol. 2020;267(7):1877-9. https://doi.org/10.1007/s00415-020-09849-6

12. Alberti $P$, Beretta S, Piatti $M$, Karantzoulis $A$, Piatti ML, Santoro $P$, et al. Guillain-Barré syndrome related to COVID-19 infection. Neurol Neuroimmunol Neuroinflamm. 2020;7(4):e741. https:// doi.org/10.1212/NXI.0000000000000741

13. Assini A, Benedetti L, Di Maio S, Schirinzi E, Del Sette M. New clinical manifestation of COVID-19 related Guillain-Barrè syndrome highly responsive to intravenous immunoglobulins: two Italian cases. Neurol Sci. 2020;41(7):1657-8. https://doi. org/10.1007/s10072-020-04484-5

14. Ottaviani D, Boso F, Tranquillini E, Gapeni I, Pedrotti G, Cozzio $S$, et al. Early Guillain-Barré syndrome in coronavirus disease 2019 (COVID-19): a case report from an Italian COVID-hospital. Neurol Sci. 2020;41(6):1351-4. https://doi.org/10.1007/ s10072-020-04449-8

15. Riva N, Russo T, Falzone YM, Strollo M, Amadio S, Del Carro U, et al. Post-infectious Guillain-Barré syndrome related to SARS-CoV-2 infection: a case report. J Neurol. 2020;267(9):2492-4. https:// doi.org/10.1007/s00415-020-09907-z

16. Zhao H, Shen $D$, Zhou H, Lu J, Chen $S$. Guillain-Barré syndrome associated with SARS-CoV-2 infection: causality or coincidence? Lancet Neurol. 2020;19(5):383-4. https://doi.org/10.1016/ S1474-4422(20)30109-5

17. Virani A, Rabold E, Hanson T, Haag A, Elrufay R, Cheema T, et al. Guillain-Barré syndrome associated with SARS-CoV-2 infection. IDCases. 2020;20:e00771. https://doi.org/10.1016/j. idcr.2020.e00771

18. Rana S, Lima AA, Chandra R, Valeriano J, Desai T, Freiberg W, et al. Novel coronavirus (COVID-19)-associated Guillain-Barré syndrome: case report. J Clin Neuromuscul Dis. 2020;21(4):240-2. https://doi.org/10.1097/CND.0000000000000309 
19. Su XW, Palka SV, Rao RR, Chen FS, Brackney CR, Cambi F. SARS-CoV-2-associated Guillain-Barré syndrome with dysautonomia. Muscle Nerve. 2020;62(2):E48-9. https://doi. org/10.1002/mus.26988

20. Lantos JE, Strauss SB, Lin E. COVID-19-associated Miller Fisher syndrome: MRI findings. AJNR Am J Neuroradiol. 2020;41(7):1184-6. . https://doi.org/10.3174/ajnr.A6609

21. Camdessanche JP, Morel J, Pozzetto B, Paul S, Tholance Y, Botelho-Nevers E. COVID-19 may induce Guillain-Barré syndrome. Rev Neurol (Paris). 2020;176(6):516-8. https://doi. org/10.1016/j.neurol.2020.04.003

22. ArnaudS, BudowskiC, Tin S, Degos B. Post SARS-CoV-2 GuillainBarré syndrome. Clin Neurophysiol. 2020;131(7):1652-4. https://doi.org/10.1016/j.clinph.2020.05.003

23. Bigaut $K$, Mallaret $M$, Baloglu S, Nemoz B, Morand P, Baicry F, et al. Guillain-Barré syndrome related to SARS-CoV-2 infection. Neurol Neuroimmunol Neuroinflamm. 2020;7(5):e785. https:// doi.org/10.1212/NXI.0000000000000785

24. El Otmani H, El Moutawakil B, Rafai MA, El Benna N, El Kettani C, Soussi M, et al. Covid-19 and Guillain-Barré syndrome: more than a coincidence! Rev Neurol (Paris). 2020;176(6):518-9. https://doi.org/10.1016/j.neurol.2020.04.007

25. Juliao Caamaño DS, Alonso Beato R. Facial diplegia, a possible atypical variant of Guillain-Barré syndrome as a rare neurological complication of SARS-CoV-2. J Clin Neurosci. 2020;77:230-2. https://doi.org/10.1016/j.jocn.2020.05.016

26. Galán AV, Del Saz Saucedo P, Postigo FP, Paniagua EB. Guillain-Barré Syndrome associated with SARS-CoV-2 infection. Neurologia. 2020;35(4):268-9. https://doi.org/10.1016/j.nrl.2020.04.007

27. Marta-Enguita J, Rubio-Baines I, Gastón-Zubimendi I. Fatal GuillainBarre syndrome after infection with SARS-CoV-2. Neurologia. 2020;35(4):268-9. https://doi.org/10.1016/j.nrl.2020.04.007

28. Molina AE, Martínez MM, Chueca PS, López AC, Val IS, Sanjuan-Villarreal TA. Guillain-Barré syndrome associated with SARS-CoV-2 infection. Med Intensiva. 2020;44(8):513-4. https://doi.org/10.1016/j.medin.2020.04.015
29. Sancho-Saldaña A, Lambea-Gil A, Liesa JLC, Caballo MRB, Garay MH, Celada DR, et al. Guillain-Barré syndrome associated with leptomeningeal enhancement following SARS-CoV-2 infection. Clin Med (Lond). 2020;20(4):e93-4. https://doi. org/10.7861/clinmed.2020-0213

30. Reyes-Bueno JA, García-Trujillo L, Urbaneja P, Ciano-Petersen NL, Postigo-Pozo MJ, Martínez-Tomás C, et al. MillerFisher syndrome after SARS-CoV-2 infection. Eur J Neurol. 2020;27(9):1759-61. https://doi.org/10.1111/ene.14383

31. Chan JL, Ebadi H, Sarna JR. Guillain-Barré syndrome with facial diplegia related to SARS-CoV-2 infection. Can J Neurol Sci. 2020;47(6):852-4. https://doi.org/10.1017/cjn.2020.106

32. Coen M, Jeanson G, Culebras Almeida LA, Hübers A, Stierlin F, Najjar I, et al. Guillain-Barré syndrome as a complication of SARS-CoV-2 infection. Brain Behav Immun. 2020;87:111-2. https://doi.org/10.1016/j.bbi.2020.04.074

33. Lascano AM, Epiney JB, Coen M, Serratrice J, Bernard-Valnet $\mathrm{R}$, Lalive PH, et al. SARS-CoV-2 and Guillain-Barré syndrome: AIDP variant with a favourable outcome. Eur J Neurol. 2020;27(9):1751-3. https://doi.org/10.1111/ene.14368

34. Helbok R, Beer R, Löscher W, Boesch S, Reindl M, Hornung $R$, et al. Guillain-Barré syndrome in a patient with antibodies against SARS-COV-2. Eur J Neurol. 2020;27(9):1754-6. https:// doi.org/10.1111/ene.14388

35. Kilinc D, van de Pasch S, Doets AY, Jacobs BC, van Vliet J, Garssen MPJ. Guillain-Barré syndrome after SARS-CoV-2 infection. Eur J Neurol. 2020;27(9):1757-8. https://doi. org/10.1111/ene.14398

36. Oguz-Akarsu E, Ozpar R, Mirzayev H, Acet-Ozturk NA, Hakyemez $B$, Ediger $D$, et al. Guillain-Barré syndrome in a patient with minimal symptoms of COVID-19 infection. Muscle Nerve. 2020;62(3):E54-7. https://doi.org/10.1002/mus.26992

37. Scheidl E, Canseco DD, Hadji-Naumov A, Bereznai B. GuillainBarré syndrome during SARS-CoV-2 pandemic: a case report and review of recent literature. J Peripher Nerv Syst. 2020;25(2):204-7. https://doi.org/10.1111/jns.12382. 